Троян Д. М., аспірант кафедри української літератури і компаративістики, Київський університет імені Бориса Грінченка

\title{
МІКРОПОЕТОЛОГІЧНІ ІННОВАЦІї В РОМАНАХ Л.-Ф. СЕЛІНА
}

У статті розглядаються найбільш сутнісні авторські новації на рівні мікропоетики роману Луї-Фердінана Селіна «Подорож на край ночі», зокрема, в лексиці й синтаксисі твору. Результати дослідження дають можливість зробити ряд висновків про формування принципово нового типу художнього ијлого в романі.

Ключові слова: мікропоетика, Л.- Ф Селін, поетика, роман.

В статье рассматриваются наиболее сущностные авторские новачии на уровне микропоетики романа Луи-Фердинанда Селина «Путешествие на край ночи», в частности, в лексике и синтаксисе произведения. Результаты исследования позволяют сделать ряд вывводов о формировании принципиально нового типа художественного целого в романе.

Ключевые слова: микропоетика, Л.-Ф Селин, поэтика, роман.

The article deals with the most important authorial innovations at the level of micro-poetics of the novel "Journey to the End of the Night" by Louis-Ferdinand Celine, in particular lexical and syntactic. The results of the study give an opportunity to make a number of conclusions about the formation of a fundamentally new type of artistic whole in the novel.

Keywords: micro-poetics, L.-F. Celine, poetics, novel.

Попри значну історичну дистанційованість, рецепція творчості Л.-Ф. Селіна досі становить значну теоретичну та ідеологічну проблему - надто істотними виявилися втілені в текстах Селіна поетологічні новації. Роман «Подорож на край ночі» разюче вирізнявся на тлі сучасної йому літератури, й у кожному з наступних творів цей розрив лише збільшувався.

Селін відкрив для літератури неохопну сферу до того зневаженої побутової мови: мови, для якої не існують норми пристойності, і яка, водночас, виявляє інакші, не досліджені до того можливості образності й виразності.

Метою цієї статті є виокремлення найбільш сутнісних авторських новацій на рівні мікропоетики роману Луї-Фердінана Селіна «Подорож на край ночі».

Роман «Подорож на край ночі» блискуче обгрунтував твердження, що побутова мова цілком придатна для написання художньго твору. Це заперечувало загальновизнану привілейованість літературної мови, яка до того протягом кількох століть не ставилася під сумнів. Селін зробив спробу створення принципово іншого роману, який може бути протиставлений роману 
традиційному. Зокрема одним із виявів полеміки автора 3 традицією є теза: «Так казав Літре, а він ніколи не помиляється» [Селін 2006:18]. Ідеться про Еміля Літре (1801-1881) - французького філолога і філософа-позитивіста, автора класичного «Словника французької мови», Мова роману, попри точне відтворення мовленнєвих конструкцій, що притаманні саме розмовній, а не літературній мові, є не записом чужого мовлення, а системою стилю зі своїми іманентними правилами. Селін знайшов спосіб передати письмово логіку і рух усного мовлення. Хід думки, форма іï вираження залежать від мовленнєвої ситуації, коли думка оформлюється в слова, від особистих реакцій мовця. Селін відтворив на письмі синтаксичну конструкцію, що імітує структуру усного висловлювання, додавши в речення займенник, що дублює іменник у тому ж реченні, й виносячи вперед, на найважливіше місце, слово, найбільш важливе для мовця - за змістом і емоційним впливом [Селин 1994]. «Спочатку було не слово, спочатку була емоція», - цей вислів ілюструє основний механізм поетики Селіна, їі рушійну силу: “"ресенсібілізувати мову, аби вона більше тріпотіла, а не розмірковувала - ТАКА МОЯ МЕТА...”. Хоча иุі пошуки емоційної глибини формулюються в термінах субстаниіонального занурення в “саму суть речей“, Селін - перший, хто зрозумів, щзо тільки мелодія відтворює, і навіть утримує, цุю заховану інтимність. Культ емоції перетікає таким чином в прославляння звуку» [Кристева 2003:226] (як тут не згадати «Народження трагедії з духу музики» Ніцше?). Здобувши реноме найбільш злободенного письменника серед сучасників завдяки нищівній критиці усіх можливих і неможливих суспільних устроїв, Селін, проте, виявився значно складнішим явищем, ніж його воліли трактувати. Теза про те, що Селін говорить так само, як пише, неодноразово повторювана самим автором, є істотним спрощенням і спонукає до дискусії. Жодна людина не говорить так, як пише Селін. Розгадку слід шукати в задачах, які ставив перед собою автор, виконання яких вимагало нових, принципово відмінних від звичних засобів вираження, зокрема, такого, як звертання до чужої мови: «Де немає адекватної форми для безпосереднього вираження авторських інтенцій, доводиться вдаватися до заломлення їх в чужому слові. 
Іноді ж самі художні завдання такі, щзо їх взагалі можна здійснити лише иляхом двуголосся слова» [Бахтин 1994:90]. Власне, йдеться про описану М. Бахтіним на прикладі романів Ф. Достоєвського групу художньомовленнєвих явищ (стилізація, пародія, оповідь, діалог), дослідження яких вимагає, за Бахтіним, підходу, що «...не вкладається в межі звичайного стилістичного і лексикологічного підходу» [Бахтин 1994:83]. В експериментах 3 мовою художнього твору Селін просувається далі, вдаючись до словотворення. Ідеться про численні неологізми, що були винайдені ним: іменники, прикметники, дієслова, прийменники, (близько 340 неологічних словоформ, утворених, здебільшого, за допомогою додавання суфіксів -ailleur, -ailler, -ouiller, -oter, -tion, -eux, -euse та ін.) [Аристова 2012:14]. Майстерне володіння прийомами конверсії та субстантивації свідчить не лише про глибоке знання рідної мови, а й про прагнення до віднайдення нових, відповідних художнім задачам засобів вираження. Новація не обмежилася лише мовою оповіді. Вочевидь не ставивши собі це за мету, Селін послідовно ставить під сумнів усі надбання традиції французького роману. На зміну усталеній романній композиції приходить вільна композиція, до якої додаються відсутність чітко вираженого сюжету та зумисна непослідовність оповіді. У передмові до видання роману українською мовою Д. Наливайко наголошує: «У ньому відсутній романний сюжетний кістяк, щуо організовує твір $i$ надає йому завершеності, цуе справді вільна відкрита композиція, в якій елементи традииійного роману поєднуються з автобіографією, мемуарами, сповіддю, розповідями про мандри тощу, які належать до поn-fiction, небелетристичних жанрів. Та в «Подорожі...» $з$ усіх цุих елементів витворюється жива, органічна художня тканина» [Селін 2006:15]. Гіперреалістичність оповіді компенсується істотними відступами від реалістичних установок, а романний хронотоп характеризується специфічним відчуттям реальності - гіперреалізм Селіна найточніше характеризується визначенням Ж. Лакана «галюциногенна реальність». Специфічна логіка галюцинації проходить скрізь весь роман. Цю логіку неможливо збагнути у відриві від біографії Селіна, життєвий шлях якого 
ставить під сумнів саму можливість інтелектуального пізнання як адекватного засобу освоєння дійсності. Звертаючись до традиційно знехтуваних у французькій літературі можливостей фантастики, Селін вводить у роман Робінзона - двійника головного героя роману Бардамю. Після цього істотного першого - відступу від правдоподібності як основи реалізму, в оповіді виникатимуть такі елементи фантастики, що поривають з реалізмом: Бардамю опиняється на галері, куди його продали в статусі гребця, - подія, цілком неможлива в часи, коли відбувається дія роману (нагадаємо, дія відбувається в роки Першої світової війни та після неї. Востаннє галери були використані під час Наполеонівських воєн). Автор ніби запрошує читача до гри, перевіряючи його пильність численними зумисне допущеними анахронізмами: Мейфлауер прибув до Америки не в 1677 [Селін 2006:49], а в 1620 році, така ж плутанина відбувається з датами у післявоєнних романах «Німецької трилогії». Навряд чи письменник міг допустити численні анахронізми ненавмисне. Селін ніколи не робив спроб систематизувати свої думки стосовно поетики художнього твору, надаючи перевагу метафоричним висловлюванням. Метафора, яка для Селіна $є$ основним тропом, може бути пояснена лише за допомогою іншої метафори цей прийом для пояснення особливостей авторського письма набув широкого вжитку в численних дослідженнях, присвячених творчості Селіна (тут можна навести не один десяток прикладів від «слова проникали в кров як спирт» Віктора Срофєєва [Ерофеев 1986:228] до «Селін доводить ияю техніку <...> до пароксизму» у Юлї̈ Крістевої [Кристева 2003:173]). Попри вдавану легкість письма, цей автор був і лишається архіскладним автором як для дослідника, так і для пересічного читача. Значною мірою вищенаведені приклади зумовлюють винятковість того місця в літературі XX ст, який відведено Селіну. Спричинивши революцію в мові художнього твору, наслідком якої стали численні спроби наслідування, ця поетика не зазнала подальшого органічного розвитку. Край ночі виявився місцем, де закінчуються будь-які перспективи. Цей висновок підтверджується й плідними спробами підступитися до Селіна за допомогою лаканівського психоаналізу та деконструкції - методів, що виникли 
значно пізніше за його роман, які, розширюючи інтерпретаційне поле, дають якісно інші результати, без властивих для більш архаїчних методів спрощень i однобокого висвітлення проблеми.

\section{БІБЛІОГРАФІЯ}

Аристова 2012 - Аристова В. Лексичні способи створення інвективного ефекту у творі Л.-Ф. Селіна «Voyage au bout de la nuit»/ В. Аристова // Гуманітарна освіта у технічних вищих навчальних закладах : зб. наук. праць. 2012. - № 26. - C. 7-17.

Бахтин 1994 - Бахтин М. М. Проблемы поэтики Достоевского / М. М. Бахтин. - 5-е изд., доп. - К. : NEXT, 1994. - 508 с.

Ерофеев 1986 - Ерофеев В. Путешествие Селина на край ночи / В. Ерофеев // Иностранная литература. - 1986. - № 11. - С. 228-237.

Кристева 2003 - Кристева Ю. Силы ужаса: эссе об отвращении / пер. с фр. А. Костиковой. - Харьков : Ф-Пресс, 2003. - 256 с.

Предисловие к русскому изданию А. Годара в переводе Т. Балашовой [Електронний ресурс] // Селин Л.-Ф. Путешествие на край ночи: Роман. - М., 1994. - Режим доступу: // http://lib.ru/INPROZ/SELIN/kraj_ nochi.txt

Селін Л.-Ф. Подорож на край ночі: роман / Луї-Фердінан Селін / пер. 3 фр. П. Таращука ; передм. Д. Наливайка. - Х. : Фоліо, 2006. - 367 с. 